\title{
TULIP: Sejarah Teologi Calvinis di Belanda 1618-1619
}

\author{
Mery Wenas \\ Aktivis Gereja Masehi Injili di Minahasa \\ Mery17wenas@gmail.com
}

\begin{abstract}
Abstrak
Tujuan penelitian ini yaitu untuk meneliti sejarah perkembangan Calvinisme di Belanda yang dibawah oleh Johanes Calvin di masa 1618-1619 dan pengaruhnya bagi gereja di Indonesia. Salah satu teologi Calvinis yang lahir dan berkembang di Belanda yakni TULIP. Melalui perkembangan di Belanda, penyebarluasan teologi predestinasi yang terkandung dalam TULIP maupun beberapa teologi lainnya boleh dikenal sampai di Asia khususnya gereja di Indonesia seperti Gereja Masehi Injili di Minahasa (GMIM). Metode yang digunakan yakni penelitian kualitatif dengan studi literatur. Kesimpulan penelitian ini adalah dengan adanya TULIP, GMIM perlu mengkaji kembali kesadaran bersama menjalankan teologi (doing theology) dengan berbagai persoalan dan tantangan yang dihadapi gereja.
\end{abstract}

\section{Kata Kunci: Tulip, Calvinis, GMIM}

\section{LATAR BELAKANG}

Johannes Calvin adalah salah satu tokoh reformasi atau reformator yang terkenal di abad Pertengahan setelah Martin Luther dan Ulrich Zwingly yang memberi respon terhadap praktek yang dilakukan oleh Gereja Katolik Roma pada waktu itu. Reformasi adalah gerakan keagamaan abad ke 16 yang melakukan penolakan terhadap beberapa ajaran serta kebiasaan Gereja Katolik Roma dan yang menghasilkan pendirian gereja-gereja reformasi. ${ }^{1}$

Johannes Calvin lahir pada tanggal 10 Juli 1509 di kota Noyon, Perancis Utara. Calvin pernah hidup dan bertumbuh dalam

${ }^{1}$ Napel, Kamus Teologi: Inggris-Indonesia, (Jakarta: BPK Gunung Mulia, 2009), h. 266. lingkungan orang-orang "berdarah biru" bangsawan yang ada di Perancis. Hidup dalam lingkungan tersebut telah membentuk sikap, mental dan tingkah lakunya di kemudian hari sebagai salah satu pemimpin terkemuka. Ayahnya bernama Gerard Cauvin seorang pegawai Uskup di Noyon. Ibunya Jeanne Lefranc meninggal ketika usia Calvin masih muda. Bahasa Perancis adalah bahasa ibunya. Ia dilahirkan dengan nama Jean Chauvin atau Cauvin dan versi Latinnya adalah, Calvinus. ${ }^{2}$ Nama panggilannya yaitu Calvin. Istri Calvin ialah Idelette de Bure, janda yang dulunya adalah anggota Anabaptis di Strasbourg, dan ia

2 Berkhof, H \& Enklaar, I. H., Sejarah Gereja. (Jakarta: BPK Gunung Mulia, 2005), h. 157. 
sempat memiliki seorang anak laki-laki yang dua minggu kemudian meninggal. ${ }^{3}$

Penyimpangan

dan

ketidakketeraturan norma yang terjadi di tengah-tengah umat menghasilkan kesadaran untuk melakukan reformasi saat itu, Gereja menyampaikan ajaran yang sudah tidak lagi sesuai dengan maksud Tuhan Allah lewat Firmannya di dalam Alkitab, melainkan kehendak otoritas gereja semata. Jika ditarik dari akar katanya, Reformasi diambil dari bahasa Inggris, dua kata yang terpisah yaitu Re yang artinya kembali dan form yang artinya membentuk, jadi reformasi memiliki arti lama. ${ }^{4}$

Adapun yang menjadi dasar dari segala sesuatu yang dibuatnya yaitu Alkitab. Jelaslah bagi Calvin sumber ajaran Kristen adalah Alkitab. Alkitab mengandung Firman Allah, sehingga pengajaran agama Kristen berarti pengajaran Alkitab. Dalam Institusio Calvin selalu berbicara mengenai Allah dan manusia. Pertama-tama Calvin menekankan bahwa kemuliaan Allah (Gloria Dei) adalah tujuan utama dari segala-galanya, baik untuk Allah maupun untuk manusia. ${ }^{5}$ Pengajaran agama Kristen, katekisasi, dan tata gereja. Pengakuan iman disusunnya untuk di

${ }^{3} \mathrm{http} / / /$ id.wikipedia.org/wiki/Yohanes Calvi n. Diunduh tgl 02/11/11.

4 Soedarmo R., Kamus Istilah Teologi (Jakarta: BPK Gunung Mulia, 2010), h. 78.

${ }^{5}$ Ibid., hal. 54-55. terapkan. Meskipun harus disadari karyakarya Calvin tidak hanya terbatas pada buku Institusio namun, Calvin sendiri menganggap buku tersebut sebagai ringkasan dari kompedium teologinya. ${ }^{6}$

Merujuk pada konteks gereja masa kini, penulis mendapati ada banyak sekali masalah-masalah yang muncul dalam gereja baik dari luar maupun dari dalam. Ketika kita merujuk pada konteks Persatuan Gerejagereja di Indonesia lebih khusus lagi Gereja Masehi Injili di Minahasa, fakta membuktikan bahwa banyak persoalan yang dipertikaikan gereja sampai saat ini belum dapat memberikan jawaban atau solusi yang tepat. Masalah yang dianggap kecil pun ternyata memiliki dampak besar bagi pertumbuhan iman jemaat.

Beberapa persoalan GMIM yang boleh dikemukakan saat ini yakni mulai dari segi keorganisasian dalam tiap-tiap jemaat, konsep tata gerejanya, solusi terhadap masalah-masalah sosial (kekerasan, LGBT, kemiskinan), konsep-konsep dalam beribadah yakni homiletika dan liturgika, serta masalah-masalah lain sebagainya. Jadi, meskipun harus disadari terdapat banyak persoalan di dalamnya, GMIM haruslah

\footnotetext{
${ }^{6}$ Jonge, Christian de. Apa itu Calvinisme?. (Jakarta: BPK Gunung Mulia, 2011), h. 53.
} 
mampu untuk memberikan jawaban terhadap-persoalan-persoalan tersebut.

\section{KERANGKA TEORI}

\section{Calvinis}

Calvinis merupakan orang-orang yang menganut dan mengambil bagian dari pemahaman teologi Calvin untuk dikembangkan dan diterapkan dalam suatu komunitas yang mengakuinya. Dengan kata lain pengikut Calvin disebut Calvinis. ${ }^{7}$ Sedangkan Calvinisme adalah sistem teologi yang dirumuskan oleh Johannes Calvin dalam karyanya yang utama yaitu Institutio dan diterima dengan banyak perubahan oleh gereja-gereja non-Lutheran. Corak teologi Calvin jelas dalam komunitas reformasi. ${ }^{8}$

Pada abad XVI Calvinisme dikenal sebagai sebuah gerakan yang ikut mereformasikan atau membaharui Gereja Katolik Roma pada abad Pertengahan. Alkitab digunakan sebagai dasar bagi manusia dalam mendalami dan memahami akan Allah serta karya-karya-Nya, yang hendak disampaikan kepada manusia lewat penyertaan Roh Kudus. Dalam Calvinisme terdapat suatu ajaran penting mengenai

${ }^{7}$ Aritonang, Jan Sihar, Garis Besar Sejarah Reformasi (Bandung: Jurnal Info Media 2007), h. 98.

8 Wellem, F. D. Kamus Sejarah Gereja. (Jakarta: BPK Gunung Mulia, 2009), h. 52-53. predestinasi. $^{9} \quad$ Predestinasi memberikan penekanan pada keputusan pemilihan Allah yang kekal berdasakan kedaulatan dan keputusan-Nya semata. $^{10}$ Dalam usaha pemilihan atau penetapan kepada siapa keselamatan dialamatkan, tidak sedikitpun di dalamnya mengandung "interfensi". Bahkan manusia sendiri tidak mampu untuk memahami kedaulatan Allah berdasararkan pemilihan tersebut. Selain itu pemerintahan Allah dalam konteks gereja dan negara sangat dijunjung tinggi dalam ajarannya. Sisi penting yang harus dicapai gereja dan negara yakni, gereja dan negara harus benarbenar mengedepankan keadilan dalam pemerintahannya.

Dari sekian banyak gereja-gereja yang menganut dan lahir dari paham ini sering tidak menyebut diri secara terangterangan sebagai Calvinis. Dalam komunitasnya, mereka lebih suka menggunakan kata reforme (Perancis); reformed (Inggris); reformiert (Jerman); gereformeerd "yang direformasikan" atau Hervormd "dibentuk kembali: sebutan setelah adanya perpecahan gereja Gereformeerd" (Belanda), yang artinya telah

\footnotetext{
${ }^{9}$ Ibid.

10 Calvin, Yohanes. INSTITUTIO, Pengajaran Agama Kristen. (Jakarta: BPK Gunung
} Mulia, 2011), h. 54-56. 
direformasikan sesuai dengan Firman Allah daripada sebutan Calvinis tersebut. ${ }^{11}$

\section{Tulip}

Belanda merupakan salah satu tempat di mana teologi Calvin diterapkan dan dikembangkan oleh para pengikutnya. Salah satu teologi yang lahir dan berkembang di Belanda adalah teologi Calvinis yakni TULIP. Melalui perkembangan di Belanda, penyebarluasan teologi predestinasi yang terkandung dalam TULIP maupun beberapa teologi lainnya boleh dikenal sampai di Asia khususnya di Indonesia. Dalam TULIP, Calvinis di Belanda mengakui bahwa satu-satunya sumber keselamatan manusia adalah Allah. Melalui kedaulatanNya Ia menganugerahkan dan menetapkan kepada manusia secara cuma-cuma jaminan kekal yaitu keselamatan. Dengan kata lain pokok teologi predestinasi yang dikembangkan Calvinis di Belanda sama seperti inti atau pokok dari pemikiran teologi predestinasi Calvin yang telah dijabarkan dalam bab I, bahwa keselamatan hanya bersumber dari Allah, berdasarkan kedaulatanNya serta kekuasaan penuh yang berada di tangan-Nya. Tidak ada satupun lembaga di luar Allah yang bisa mengambil alih atau diberikan wewenang dari Allah untuk melaksanakan atau

\footnotetext{
${ }^{11}$ Jonge Christiane de, Op. Cit, h. 11.
}

membagi-bagikan keselamatan tersebut. Gereja dalam hal ini merupakan saluran atau pangkalan, namun bukan berarti gereja berdiri sebagai pemegang hak dalam membagi-bagikan keselamatan.

Latar belakang munculnya rumusan TULIP sebagai The Canons of Dort di Belanda awalnya disebabkan oleh masalah atau konflik yang terkait erat dengan seluruh kompleksitas kehidupan politik, militer, dan sosial di negeri Belanda. Masalah kompleksitas ini kemudian memanfaatkan gereja yang di dalamnya gereja sendiri banyak mengalami pergumulan yang memerlukan jalan keluar. masalah baru kemudian berlanjut dengan adanya pro dan kontra terhadap ajaran Calvinis mengenai predestinasi pada akhir abad ke 16 dan awal abad ke $17 .{ }^{12}$

Pertikaian mengenai ajaran predestinasi ini kembali terjadi di Belanda setelah sekian lama ajaran Augustinus menentang hal yang sama yang dikemukakan oleh pengikut Pelagianisme di akhir abad mula-mula. Ajaran ini pada dasarnya bersumber dari Alkitab terutama dalam surat-surat Paulus dan kemudian diberi perhatian oleh Augustinus. Dalam surat-surat Paulus predestinare atau

12 Berkhof, H \& Enklaar, I. H., Sejarah Gereja. (Jakarta: BPK Gunung Mulia, 2005), h. 207. 
predestinasi ini terdapat pada Roma 8:29-30 dan Efesus 1:5-11, yang menyangkut jaminan dan kepastian keselamatan orangorang percaya kepada Kristus berdasarkan kedaulatan Allah, Dia menentukan siapa yang dipilih untuk diselamatkan dan siapa yang ditolak. ${ }^{13}$

Suatu tema sentral dari pemikiran Augustinus adalah kejatuhan dari hakikat manusia. Gambaran kejatuhan diambil dari kitab Kejadian pasal 3 dan menyatakan ide bahwa hakikat manusia telah "jatuh" dari status aslinya yang mula-mula. Keadaan hakikat manusia dengan demikian bukanlah merupakan apa yang dikehendaki Allah. Augustinus menggambarkan dosa sebagai sesuatu yang hakiki telah melekat pada keberadaan manusia. Dia telah hilang, rusak atau hancur, tetapi bukan berarti tidak dapat diselamatkan. Karena semua orang telah berdosa, maka semuanya memerlukan penebusan. Menurut Augustinus Allah campur tangan di dalam dilema manusia. Allah sebenarnya tidak harus melakukan hal tersebut, akan tetapi oleh karena kasih-Nya kepada manusia yang berdosa, Ia telah masuk ke dalam keadaan manusia dalam diri Yesus Kristus supaya menebus manusia. ${ }^{14}$

\footnotetext{
13 Aritonang, Op. Cit., h. 99.

${ }^{14}$ McGrath, Aliester E. Sejarah Pemikiran Reformasi. Jakarta: BPK Gunung Mulia, 2011), h. 92-93.
}

Augustinus melihat bahwa keselamatan merupakan bagian dari keseluruhan karunia Allah dari mula dan seterusnya. Karunia itu tidak diberikan kepada semua orang karena tidak semua orang percaya kepada-Nya. Augustinus meletakan tekanan yang sedemikian kuat atas anugerah sehingga ia sering disebut sebagai doctor gratiae "doctor anugerah". Anugerah adalah pemberian Allah yang sebenarnya tidak layak kita terima, atau merupakan pemberian Allah tanpa jasa apapun dari manusia, Allah secara sukarela mematahkan cengkraman dosa atas manusia. Penebusan hanya dimungkinkan sebagai pemberian Allah. ${ }^{15}$

Hal yang menarik belum diteliti melihat persoalan dan pergumulan yang dihadapi Gereja Masehi Injili di Minahasa yang beraliran Calvinis dalam situasi menjalankan hakekat bergereja dengan berpedoman ajaran Tulip yang ditulis oleh Johannes Calvin.

\section{HASIL DAN PEMBAHASAN}

Muncul sisi negatif sejarah lahirnya TULIP di mana kaum Calvinis yang dalam kapasitas cukup besar pada waktu itu seakan-akan tidak adil dalam mengadakan suatu persidangan, di mana yang menjadi

\footnotetext{
${ }^{15}$ McGrath, Op. Cit., h. 93-94.
} 
penentu adalah pengikut Calvinis itu sendiri. Hasil yang berbeda bisa saja terjadi apabila yang menjadi pemimpin dalam persidangan tersebut adalah orang-orang di luar dari kedua kelompok yang bermasalah ini. Di samping itu kaum Calvinis sendiri tidak dapat membuktikan dengan data dan bukti yang nyata serta bisa diterima oleh mereka yang berpegang erat pada pandangan tersebut mengenai jaminan keselamatan setiap pribadi. Dasar-dasar Alkitabiah dari kaum Calvinis pun pada waktu itu tidak memiliki bukti sejauh mana dosa yang dilakukan manusia sehingga membuat manusia itu rusak atau sangat berdosa dan tidak memiliki kesempatan dalam memperoleh jaminan kekal.

Oleh karena itu dengan adanya pertikaian hingga disepakatinya keputusan yang melahirkan teologi Calvinis TULIP, maka kita pun diberikan kesempatan untuk memperhatikan dan mendalami lebih jauh sehingga dapat mengambil makna sebagai bahan untuk berefleksi dan menjawab masalah dalam konteks di manapun kita berada Tidak bisa dipungkiri, GMIM adalah salah satu anggota dalam persekutuan gereja-gereja Indonesia yang melanjutkan dan mengembangkan tradisi Calvinisme. Teologi dari Alkitab, tradisi kebudayaan dan proses perkembangan masyarakat harus diterapkan melalui kehidupan tata gereja, ajaran-ajaran dan sikap mengungkapkan imannya di tengah-tengah masyarakat. Menurut pengakuan tata gereja GMIM tahun 2007, dituliskan bahwa Gereja Masehi Injili di Minahasa sebagai gereja mandiri ditata dalam sistem presbiterial Sinodal berdasarkan pemerintahan Tuhan Allah dan Yesus Kristus. ${ }^{16}$ Presbiterial Sinodal yang diakui sebagai ciri khas kepemimpinannya, namun kenyataanya semangat episkopal dan kongregasional terkadang dipraktekkannya. ${ }^{17}$

Berkaca pada aliran Calvinis yang berkembang di Belanda, berdasarkan tata gerejanya para penatua dan pendeta dalam hal ini memiliki tanggung jawab yang sama, yaitu sebagai pemimpin jemaat dalam mengawasi dan menegur anggotaanggotanya. Pengambilan keputusan dilakukan dengan begitu ketat yaitu dengan melakukan kesepakatan dalam sidang sinode, bahkan membutuhkan waktu yang lama dan masukan-masukan serta kesepakatan dari utusan-utusan gereja Calvinis tetangga dalam menentukan

16 Tata Gereja GMIM Tahun 2007, h. 5.

17 J. M. Saruan, Ekklesiologi Calvinisme dan Pengembangannya Bagi Gerakan Ekumenis Suatu Refleksi Teologi Sistematis; Dalam Buku Berjalan Dengan Allah "Buku Peringatan 40 Tahun Fakultas Teologi UKIT 1962-2002, penyunting; Augustien Kaunang et al., (Tomohon, 2003), h. 9495. 
hasilnya. ${ }^{18}$ Tindakan-tindakan dalam rangka pengambilan keputusan tersebut terkadang tidak digunakan lagi dalam konteks gereja masa kini (GMIM). Itu disebabkan keputusan sidang yang dilakukan hanya berdasarkan keputusan pemimpin tertinggi dalam keorganisasiannya yakni ketua sinode atau pendeta sebagai ketua jemaat pun pendeta sebagai ketua-ketua wilayah.

Hal tersebut merupakan salah satu masalah konkrit GMIM di mana sikap ketidakadilan dari para pemegang kekuasaan gereja saat ini semakin nampak. Gereja semakin bersikap otoriter (berkuasa sendiri/sewenang-wenangnya) di mana, gereja tidak lagi memberikan kesempatan pada tiap-tiap anggota yang memiliki hak sama dalam menyampaikan pendapat sebagai sebuah sumbangan pemikiran dalam pengambilan keputusan dibeberapa sidang sinode. Peran sistim organisasi presbiterial sinodal dan demokrasi yang juga telah disumbangkan kaum Calvinisme seakan tidak berguna dan tidak dapat menjadi bagian penting yang dapat membantu GMIM dalam rangka berteologi dan menjawab permasalahan dalam konteks masa kini. Gereja terlihat bukan lagi berjalan secara presbiterial sinodal melainkan 'sinodal presbiterial' di bawah

18 Jonge de, Op. Cit., h. 103. semangat otoriter dari pimpinan tertinggi sinode itu sendiri

Peraturan tentang Sinode, BAB IV (Sidang Majelis Sinode), Pasal 11 (Pimpinan Sidang Majelis Sinode), ayat 1 dan 2: Pimpinan sidang Majelis Sinode adalah Badan Pekerja Majelis Sinode. Kedua, Pimpinan sidang seksi dan rapat panitia ditetapkan oleh Sidang Majelis Sinode atas usul Badan Pekerja Majelis Sinode. ${ }^{19}$ Selain itu ada juga masalah masuknya peranan politik dalam gereja. Jabatan gerejawi terkadang digunakan sebagai sarana untuk mencapai tujuan pribadi atau satu kelompok.

Dari segi doktrinitas, akibat sering disalahartikan dan disalahterapkannya rumusan teologi Calvinis yaitu TULIP sehingga menimbulkan dampak negatif, Ajaran-ajaran Calvin dan Calvinis mengenai predestinasi yang terkandung dalam rumusan putusan sidang sinode di Belanda tahun1618-1619 secara jelas tidak lagi digunakan baik dalam katekisasi maupun khotbah oleh gereja reform di Indonesia khususnya GMIM. ${ }^{20}$

Masalah doktrin dalam GMIM saat ini pun datang dari mereka yang mengaku sebagai warga GMIM, yang kurang setuju dengan pandangan dan praktek dunamis

19 Ibid., h. 72.

${ }^{20} \mathrm{http}: / /$ www.reocities.com/thisisreformedfai th/artikel/missiology04.pdf. Diunduh tgl. 20/11/12. 
yang dilakukan oleh sebagian besar pendeta GMIM saat ini. Pro dan kontra semakin nampak ketika hal ini coba diajarkan dan diterapkan dalam persekutuan-persekutuan jemaat yang dahulunya tidak pernah melakukan praktek dunamis. Hal ini disebabkan karena kurangnya kesadaran dari para pemimpin dalam menyusun strategi pelayanan yang teologis. Hal ini pun telah menyebabkan jemaat GMIM yang haus secara rohani menjadi liar dan mencari kebutuhan rohani itu di gereja atau persekutuan lain. Kalaupun di situ mereka tidak mendapatkan Firman Tuhan yang bagus, setidaknya pujian-pujian, musik, dan pembangkitan emosi dalam kebaktiankebaktian itu membuat mereka menjadi lega (sekalipun mungkin sekali kelegaan itu adalah sesuatu yang bersifat semu/sementara). ${ }^{21}$ Karena itu, pendetapendeta gereja Protestan yang melihat dombanya 'dicuri' oleh gereja atau persekutuan Kharismatik mulai mengikuti gaya yang dipraktekkan oleh aliran ini, agar memiliki kesamaan meskipun secara kualitas bukan itu tujuannya.

GMIM yang merupakan salah satu organisasi gereja, yang kuat baik dalam sisi keorganisasian maupun persekutuan

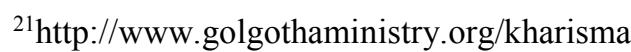
tik/kharismatik_01.htm. Diunduh tanggal 02/4/2012.
}

imannya, mulai nampak terkikis sedikit demi sedikit. GMIM kemudian menjadi sulit dalam menjawab berbagai persoalan dalam konteksnya diakibatkan karena GMIM tidak sadar akan suara kenabian yakni kebenaran yang harus dikumandangkan. GMIM pun belum bisa menampilkan diri secara tegas dan keras dalam menyampaikan suatu keputusan dalam hal menyampaikan dasar berteologinya.

Dengan adanya TULIP, gereja Calvinis di Belanda telah membuktikan bahwa mereka mampu untuk menjawab dan menyelesaikan persoalan dan pertikaian yang ada dalam konteksnya. Dengan bersikap tegas dan keras, gereja di Belanda menjawab persoalan dalam konteksnya yaitu dengan cara melahirkan suatu rumusan teologi Calvinis resmi yang mereka sebut "Pasal-pasal Ajaran Dordrecht" atau TULIP. Jika dikaji dari sejarah yang ada, GMIM sebenarnya telah memiliki landasan untuk berteologi yakni, Tata Gerejanya dan putusan-putusan resmi Persatuan Gerejagereja di Indonesia yang masuk dalam Dewan Gereja-gereja se-Dunia yaitu terdapat pada dokumen-dokumen keesaan yang diuraikan dalam Lima Dokumen Keesaan Gereja. Namun, seiring berjalannya waktu, landasan berteologi yang sebenarnya telah ada dalam rumusan Dokumen- 
dokumen Keesaan Gereja seakan tidak diaplikasikan atau dihiraukan lagi.

Entah dimengerti atau tidaknya putusan-putusan teologi yang telah dirumuskan melalui sidang-sidang raya gereja Protestan di Indonesia atau memang sengaja tidak ingin terikat dengan putusan tersebut, pastinya GMIM seakan kehilangan arah ketika diperhadapkan dengan masalah dalam konteksnya. Itu diakibatkan tidak adanya landasan berteologi yang kuat dalam tata gereja GMIM. Persoalan-persoalan yang melahirkan kontroversi di atas sebenarnya merupakan tolok ukur di mana gereja harus berkaca diri. Gereja harus sadar bahwa banyak sekali permasalahan dalam jemaat yang harus diangkat ke permukaan agar menjadi semakin jelas keberadaannya. Tata Gereja yang telah diputuskan secara resmi dalam sidang yang melibatkan seluruh anggota sidang dalam pemetaan konsepnya, haruslah benar-benar dijabarkan dan dilaksanakan dalam konteks GMIM saat ini.

Cara berteologi Calvinis yang menghasilkan pro dan kontra digambarkan sebagi hasil akhir dari berkembangnya suatu aliran yang diakibatkan karena iman Kristen gerejanya bersifat dinamis. GMIM dalam hal ini memang haruslah bersifat dinamis, karena apabila GMIM tidak dinamis maka ia tidak akan pernah mengalami pembelajaran yang hendak mengubah dan menghantarnya pada pertumbuhan iman dan perkembangan, yaitu dalam rangka membangun satu kesatuan tubuh Kristus yang utuh. Namun, dalam hal ini bukan berarti ia harus membawa gerejanya menyimpang dari arus tradisi serta jiwa dan semangat membaharui diri yang diakui dan landasan Alkitab sebagai dasarnya.

Dengan kembali melihat sejarah lahirnya TULIP kurang lebih dapat membantu GMIM dalam menjelaskan bahwa keselamatan yang dianugerahkan Allah kepada manusia adalah keselamatan yang sempurna, yakni keselamatan yang telah dinyatakan dalam Yesus Kristus sebagai jaminan dan pengantara yang lebih baik yaitu perjanjian baru. Keselamatan yang pada akhirnya merupakan jaminan kekal yang dianugerahkan Allah kepada manusia perlu dilihat sebagai kasih Allah yang sempurna berdasarkan penentuan yang bukan semata-mata harus dijawab dengan kemampuan manusia. Oleh karena itu usaha GMIM yang dilakukan dengan berbagai cara, tanpa adanya motivasi yang benar di dalam Kristus semuanya akan sia-sia.

Anugerah yang telah ditetapkan Allah itu bersifat mutlak diberikan kepada setiap orang sesuai dengan kehendakNya sejak awal, sehingga tidak ada alasan yang 
dapat mengatakan bahwa GMIM secara institusinya patut menentukan siapa yang layak dan tidak dalam menerima hal tersebut, begitu pun dengan kaum Armenian dalam penekanannya pada keputusan manusia yang mau atau tidak mau menerima anugerah tersebut. Gereja dalam hal ini GMIM harus menjadi pengantara selanjutnya setelah Kristus untuk menyampaikan dan membagi berita sukacita, yakni memperoleh jaminan kekal untuk semua orang yang percaya dan terus bertahan hingga akhirnya.

TULIP dapat menolong kita memahami prilaku Allah mulai dari ketegasanNya, kelemahlembutanNya, kekompromianNya bahkan keketatanNya dalam memilih dan menentukan sesuatu yang diinginkanNya terhadap jalan kehidupan manusia. Setelah kita memahami akan sisi central dari Allah, maka kita akan menemukan sejauh mana tanggungjawab manusia dan sejauh mana manusia harus melangkah dalam membentuk relasinya dengan Allah dalam konteks masa kini. Kita pun dapat mengetahui maksud dan tujuan serta sejauh mana Kristus melakukan segala tugasNya. Iman dan pertobatan yang dianugerahkan kepada manusia hanyalah sebagian dari pemberian Allah kepada manusia yang patut diperjuangkan. Kristus sebagai Anak Allah yang tunggal rela diberikan kepada manusia agar manusia sadar bahwa hanya oleh Kristuslah manusia akan diperdamaikan dengan Allah.

Melalui ajaran dan tata gerejanya GMIM harus benar-benar memahami kehendak Allah yang ada dalam Alkitab. Meskipun kita harus menyadari teologi yang diterapkan oleh GMIM saat ini bukanlah teologi predestinasi melainkan teologi yang berakar dari Calvinis dan kemudian diterapkan dalam teologi kontekstual. Namun, dengan adanya sejarah lahirnya TULIP kita boleh mengerti dan memahami bahwa sejak mulanya Alkitablah yang akan menjadi dasar setiap orang melakukan tugas dan tanggungjawabnya. Sejak mulanya segala sesuatu haruslah dikaji lewat Alkitab dan hal inilah yang dilakukan oleh kaum Calvinis diperhadapkan dengan masalah doktrinnya.

Memang harus disadari upaya yang dilakukan GMIM banyak yang menyimpang sehingga pro dan kontra terus dan selalu menghiasi praktek pelayanan gereja. Oleh karena itu suatu makna mendasar patut diambil untuk menjawab masalah dalam konteks gereja masa kini khususnya GMIM yaitu, melalui ketiga ajaran sola yang dikemukakan kembali oleh Martin Luther dan dipertegas oleh Calvin yakni Sola 
Scriptura, Sola Gratia dan Sola Fide. Sola Scriptura atau hanya oleh Alkitablah mendapat posisi pertama dalam ajaran Calvin. Melalui Alkitab, kita akan menemukan seluruh pertanyaan-pertanyaan mendasar mengenai konsep tentang Allah, Kristus dan Manusia.

Melalui Alkitab juga kita akan diberikan penjelasan luas bagaimana posisi Allah dalam sudut pandang yang central, yaitu segala sesuatu yang harus dipikirkan dan dipertanggungjawabkan manusia akan keberadaanNya. Dengan kembali kepada Alkitab sebagai dasar berteologi orang Kristen, maka akan dipastikan bahwa gereja dapat menjawab persoalan dalam konteksnya. GMIM saat ini memiliki peluang dalam menjawab masalah-masalah dalam konteksnya, apabila GMIM mau meletakan segala sesuatunya pada dasar berteologi yang kuat dan kokoh sepanjang sejarah yaitu Alkitab.

Sebagai langkah terakhir dari usaha untuk mengkaji isi dari Alkitab sebagai bahan atau landasan berteologi dalam konteks GMIM masa kini, maka GMIM harus melihat pentingnya peran dari para teolog-teolog dan pentingnya sebuah lembaga atau institusi pendidikan teologi yang di dalamnya melibatkan Universitas Kristen Indonesia Tomohon sebagai dapur teologi GMIM. Gereja di Belanda pada awalnya pun telah melibatkan dan menjadikan lembaga pendidikan sebagai sebuah pangkalan dalam usaha dibahasnya masalah-masalah teologis yang ada, untuk menjawab pokok persoalan doktrin predestinasi yang bercampur dengan filsafat humanisme Kristen pada waktu itu. Gereja sangat menghargai peran dari para teolog dalam dalam mengumpulkan ide-ide atau sebuah pemikiran teologis yang Alkitabiah dan bercorak Calvinis pada waktu itu. Melalui sejarah lahirnya TULIP, gereja saat ini dapat menarik makna bahwa ternyata penting sekali apabila para teolog diberikan kesempatan untuk menyampaikan buahbuah pikirannya dalam menjawab topiktopik permasalahan GMIM saat ini. Dengan sedikit menghargai dan memberikan kesempatan (bukan sebaliknya; memperumit para teolog dan sebuah lembaga) bagi para teolog-teolog dan lembaga pendidikan teologi sebagai sarana dibahasnya masalahmasalah teologis yang ada, pasti gereja pula akan mampu merumuskan dasar berteologi dalam konteksnya.

\section{KESIMPULAN}

Ajaran-ajaran Calvin mengenai tulip yang terkandung dalam rumusan putusan sidang sinode di Belanda tahun1618-1619 
belum maksimal digunakan oleh GMIM dalam katekisasi, dan khotbah serta beberapa ajaran yang tertuang dalam Tata Gereja. Karena itu, diperlukan kesadaran bersama dari gereja untuk menjalankan teologi (doing theology).

\section{DAFTAR PUSTAKA}

Aritonang, Jan Sihar, Garis Besar Sejarah Reformasi. Bandung: Jurnal Info Media 2007.

Berkhof, H \& Enklaar, I. H., Sejarah

Gereja. Jakarta: BPK Gunung Mulia, 2005.

Calvin, Yohanes. INSTITUTIO, Pengajaran Agama Kristen. Jakarta: BPK Gunung Mulia, 2011.

Jonge, Christian de. Apa itu Calvinisme?

Jakarta: BPK Gunung Mulia, 2011.

McGrath, Aliester E. Sejarah Pemikiran

Reformasi. Jakarta: BPK Gunung Mulia, 2011.

Napel, Kamus Teologi: Inggris-Indonesia. Jakarta: BPK Gunung Mulia, 2009.
Tata Gereja GMIM Tahun 2007, Tomohon:

Badan Pekerja Sinode GMIM, 2009.

Saruan, J. M., Ekklesiologi Calvinisme dan Pengembangannya Bagi Gerakan Ekumenis Suatu Refleksi Teologi Sistematis; Dalam Buku Berjalan Dengan Allah "Buku Peringatan 40 Tahun Fakultas Teologi UKIT 19622002, penyunting; Augustien Kaunang et al. Tomohon, 2003.

Soedarmo R., Kamus Istilah Teologi. Jakarta: BPK Gunung Mulia, 2010.

Wellem, F. D. Kamus Sejarah Gereja. Jakarta: BPK Gunung Mulia, 2009.

\section{Website}

http://www.golgothaministry.org/kharismati k/kharismatik_01.htm. Diunduh tanggal 02/4/2012.

http://id.wikipedia.org/wiki/Yohanes_Calvin . Diunduh tgl 02/11/11.

http://www.reocities.com/thisisreformedfait h/artikel/missiology04.pdf. Diunduh tgl. 20/11/12. 